\title{
The Cultivation Research of Cultural Consciousness in University English Teaching
}

\author{
Liping Gao \\ Department of Foreign Language Teaching in TongHua Normal University, Tonghua in Jilin Province. \\ 134000
}

Keyword: University, English teaching, Cultural awareness.

\begin{abstract}
This article carries on the thorough analysis and the discussion from University English teaching Chinese-adapted consciousness present situation in our China, and proposes the practical and feasible countermeasures and the measures to cultivate university English teaching culture consciousness .We hope to contribute meager strength to our country University English teaching Chinese-adapted consciousness cultivation .
\end{abstract}

\section{Introduction}

With the development of economic and cultural globalization, the differences between countries of the world's economy, politics, culture communication, become the norm, and the inevitable developing trend of English has clearly become a mainstream language in cultural exchanges, plays an important role.And, of course, the language communication and transmission does not constitute a cultural exchange, all countries should also include more important between the exchange of ideas and collision, thus cultural consciousness of college English teaching is to improve the effective communication with the rest of the world's important way.

College education in our country, college English teaching is one of the compulsory general course of university students in China, also attaches great importance to by the universities teaching units.Our country University University English teaching mainly is teaches classes the teacher take to be connected the foreign language teaching idea and the theory as the instruction, by can listen, to be able to say, can read, can write is the teaching goal, selects many kinds of teaching method and the teaching method, English language glossary, the knowledge and the application skill as well as the language study strategy which professor the student is connected, through the system classroom instruction, trains the student to utilize the language, use language synthesizing capacity nimbly.In addition, the teacher should pay great attention to in the teaching process take the big cultural context carries on the language as the backing the teaching, thus enhances the student regarding the language nimble utilization and grasping, the enhancement human relations level.

However, in our country for many years in the teaching process, the relationship between language and culture supplement each other and didn't get the attention of the education teaching.The language teaching process goal four essential factors, namely listen to, to say, to read, writes the skill already to penetrate the general teacher's and student's teaching idea, has neglected in the teaching process the language social significance and the language cultural context union, also on therefore has neglected the student to the language nimble utilization skill raise, caused our country majority of student language utilization ability bad aspect.

The language teaching process goal four essential factors, namely listen to, to say, to read, writes the skill already to penetrate the general teacher's and student's teaching idea, has neglected in the teaching process the language social significance and the language cultural context union, also on therefore has neglected the student to the language nimble utilization skill raise, caused our country majority of student language utilization ability bad aspect. 


\section{Relevant concepts defined}

Culture have broad sense and narrow sense, so in this article, the author gives a definition of culture as follows: first, the connotation of the culture is a broad and relatively vague concept; Second, a culture can be defined as a blanket of social related concept and behavior; Third, a certain social group has any system and fixed behavior or behavior patterns.Culture emphasizes strong is a social group of people have a stable behavior characteristics and way of life, including all of the group behavior and thoughts; Fourth, culture is a social group in a particular area of the same or different behavior of comprehensive, attitudes, beliefs, living habits and patterns. These possessed about the cultural limits has all contained a common information----Regardless of generalized and narrow sense culture, it all has the widespread connotation, mainly includes the manner, the belief, the custom, the idea and the behavior and so on.The author thinks that culture is the continuous development of human society in the process of inheritance and creation of material wealth and spiritual wealth.

Cultural consciousness is not strange regarding the general university teachers and the student, instructs in the book in English teaching curriculum the explanation is, "Cultural consciousness mainly is refers to the foreign culture and native place culture difference consciousness and may the sensation degree, as well as when utilization foreign language, according to the foreign language cultural pattern which uses adjusts oneself to the language cognition and the understanding and using the language carries on the human relations the independency and self-consciousness. And integrating existing research and practical experience, found that the cognitive perceptual and autonomy can be acquired through systematic training.

\section{The necessity of college English teaching cultural awareness training colleges and universities}

In an era of advocating quality-oriented education, the most important qualities of college students is the humanities and cultural awareness, in the university classroom teaching system science into human consciousness in the process of teaching pattern, consciously cultivate the students' cultural awareness, is conducive to the students' learning, growing, and success.The cultural teaching belongs to the language teaching important part, is our country English teaching primary mission, is advantageous in the student during the study language academic society and enhancement utilization language synthesizing capacity and the accomplishment.

E. American scholars Sapir, (1921) argues that "language is not independent, it has to do with culture supplement each other, mutually dependent."Thus it can be seen, the culture take the language as the backing, the language and the culture makes unites.The cultural linguistics correlation research believed that, the language formation is some national all society experience comprehensive result, it had reflected this national culture distinguishes between other nationality's all characteristics. Therefore, only in-depth understanding of the social culture of the people, will be able to accurately understand their language, the cultivation of cultural awareness plays an important role in college students' language habits. The improvement of college students' cultural awareness in the process of learning English in a certain extent, will affect their interest in English study, so as to stimulate students to learn English and stable internal motivation, thus forming an effective English teaching a virtuous cycle 。

\section{College English teaching present condition analysis of the cultural consciousness}

The university is the important place which the talented person cultivates, how besides needs professor in here teacher the student scientific culture knowledge as well as utilizes these knowledge nimbly synthesizing capacity, but also should help the student to understand consciously and grasping studies the language country the culture, the custom and the custom and so on, this also requests Our country university teachers also to be supposed to strengthen own cultural consciousness unceasingly the cultural education.But according to the English teachers in colleges and universities own cultural literacy, all belong to the middle and lower level stage. The majority of 
university English teacher teaches in the classroom is merely obeys the program of instruction to complete the goal task, has not integrated the Chinese culture and the Western culture explanation, therefore the teacher cannot satisfy the student in the classroom to the West cultural context and the cultural knowledge understanding and grasping.

As is known to all, the teaching of college English teaching material content must be combined with the real context, and be able to meet the demand of college students' learning English major.Compared with the ideal university English teaching material may take acquires the university student culture consciousness the important channel and the tool, but speaking of the current Our country University English teaching material, lacks the cultural consciousness integration.Most of the students admitted to implant in the process of cultural awareness in language teaching helps to language learning and mastering, and think that the school of English teaching materials should be selected for the important tool of information about western culture and channels.But our country English teaching material primary coverage still involved was the language knowledge and the skill training, has seriously neglected the university student culture consciousness teaching duty, not only has not involved to English related cultural context, the Chinese culture knowledge all very little involved.

\section{Raise university English teaching culture consciousness countermeasure}

Cross-cultural refers to people of different from their own national culture related customs, habits, behavior, and the understanding of the philosophy thoughts and other know enough, and able to tolerate and accept attitude towards foreign culture. There are a lot of cross-cultural communication way, such as verbal and nonverbal, face-to-face two-way one-way delay timely communication and mass media communication.Therefore set up the English teachers' intercultural consciousness also requires teachers to dabble in various cultural knowledge of English, in daily life and work in use and communication.In the process of English teaching, teachers should first establish the cultivation of the students' cultural consciousness, then defined the direction of students cultural awareness cultivation dominated.First, help students to understand the related the development history of english-speaking countries, political, and economic conditions; The second main understanding related people in English countries and our country people's life and cultural differences; Third, familiar with the religious traditions of these countries, clear their special religious beliefs;Fourth, through studying the similarities and differences between Chinese and foreign culture, deepen the understanding of Chinese culture and understanding students. While carries on the Trans-Culture consciousness raise, also must pay great attention to own mother tongue culture consciousness the raise, guides the student, to have the plan to read the Chinese culture correlation systematically the books and the magazine, not only enable the student to have the rich language knowledge, but also can promote the student to form the integrity the knowledge structure, enhances the student to control to the language with utilization synthesizing capacity.

University when formulation program of instruction, not only must consider outside language own structure and the function factor, should consider with the English correlation cultural knowledge organic synthesis, and maximum limit is clear about in the teaching process in each advancement is connected the emphasis point which the culture integrates specifically, integrates effectively the cultural teaching to in the university English teaching teaching process.

In addition, keeps pace with the times the teaching material also is raises the student culture consciousness the important tool.The university English teaching material should unify with English culture, can objectively reflect the correlation country comprehensively the national culture characteristic. In the teaching material text and the practice establishment, should many and the related cultural context and the manners and customs unifies, can explain local or this country's remarkable typical cultural characteristic effectively.The teaching material can unify the correlation cultural context knowledge to carry out English teaching activity effectively, enormously promoted the teaching Chinese-adapted consciousness raise.

Teachers in the process of English teaching, should consciously explain the knowledge points involved in the relevant cultural background knowledge, can help students better to master the 
language knowledge.

In front of the interpretation of the text, for example, systematically introduces the related background knowledge; When learning new words can be combined with the related data is introduced under the different environment and cultural tradition, for the interpretation of the lexical meaning and understanding is has different meaning and emotional color.In addition, the building teaching culture atmosphere extremely is also important.The teachers should encourage the student and the foreign teacher or the foreign student carry on the exchange, through language and thought some exchanges, can help them to understand correlation country custom, culture and behavior custom and so on.

\section{References}

[1] Gao Dan. From the cultural perspective of different figures of speech [D]. Heilongjiang, heilongjiang university foreign language institute, 2007.

[2] room cross-cultural awareness in college English teaching to cultivate [D]. China petroleum university foreign language institute, 2007.

[3] Wang Song. Under the Trans-Culture linguistic environment the human relations worry studies[D].Shanghai Foreign language University Institute of foreign languages, 2009.

[4] Liu Jiaju. Cross-cultural education in current college English teaching present situation, problems and strategies [D]. Shandong normal university foreign language institute, 2008.

[5] Teng Chunyan. Cultivation of students ' cultural awareness in college English teaching [J]. Curriculum studies (higher education), 2011 (3): 162-163..

[6] Ma Xiaoran Chen Liyan. The role of cultural awareness in college English teaching [J]. Journal of wit, 2011 (8) : 120-121. 